\title{
The Parceria Project: A Brazilian Parenting Program to Mothers with a History of Intimate Parter Violence
}

\author{
Lúcia Cavalcanti de Albuquerque Williams, Paolla Magioni Santini*, Sabrina Mazo D'Affonseca
}

The Laboratory of Violence Analysis and Prevention (LAPREV), Psychology Department, Federal University of São Carlos, São Paulo, Postcode 13565-905, Brazil

\begin{abstract}
This paper takes in consideration the association between child abuse and intimate partner violence (IPV), as well as its implications to children's healthy development. In general, parenting programs do not consider the history of IPV that participants may present. Thus, they tend to not offer a special help to victimized mothers to cope with their emotional problems and other difficulties they may face in educating their children. The present article provides a description of Projeto Parceria (Partnership Project), a Brazilian program to mothers with a history of IPV after a brief review on parenting programs. Such program encompasses two units: a psychotherapeutic and an educational one. The psychotherapeutic unit deals with the emotional aspects associated with a history of IPV, thereby maximizing the aspects of parenting skills and child behavior management of the educational unit. Examples of studies using Projeto Parceria are presented indicating positive results and suggesting future research to test the project widely in randomized control evaluations.
\end{abstract}

Keywords Child abuse prevention, Child maltreatment, Domestic violence, Intervention with mothers, Parenting styles

\section{Introduction}

Despite major advances in Psychology and Medical knowledge, as well as current strategies to protect children, it is still usual to find a high incidence of abused and neglected children all over the world [1]. Studies show that problematic parenting styles are developed, in part, by the behavioral model of origin parents, and those who had a history of aggression in childhood tend to be aggressive with their own children when becoming parents [2,3]. Thus, investigations on positive parenting are needed to interrupt violent practices endured over successive generations.

One example of this violence transmission is observed in Intimate Partner Violence (IPV) cases, when violence between parents surpasses violence towards children [4]. In a social learning approach, parenting in violent environments could be a model of aggressive/passive behavior. The abusive father is usually an aggressive behavior model for boys, and the victimized mother a passive behavior model for girls [5], which could be played in different social environments.

Nevertheless, mothers with a history of violence may also be abusive to their children, as presented in a USA national report on children wellbeing [6]. The amount of time that mothers spend with their children, combined with greater

* Corresponding author:

paolla_@yahoo.com (Paolla Magioni Santini)

Published online at http://journal.sapub.org/ijap

Copyright @ 2014 Scientific \& Academic Publishing. All Rights Reserved responsibility of childcare culturally assigned to women, are variables associated with mothers' abusive behavior [7].

Studies have also suggested that mothers may be abusive due to their struggle with poverty, single-parent households, and exposure to a higher level of stress, compared to men [8]. In addition, the support network of such mothers may be poor, and they may have a violence history in their biological family [9].

Considering the association between IPV and child abuse [4], and the importance of preventing it to interrupt the cycle of violence [3], Projeto Parceria (Partnership Project) was developed in Brazil. This paper will describe this project after a brief review of parenting programs to stress the rationale for the project's creation.

\subsection{Intimate Partner Violence (IPV) and Child Abuse}

A study conducted in the United States [10] aimed at determining the prevalence of IPV among mothers reported for child abuse. Data were collected with 5501 children around the country, randomly selected by a national survey, which investigated child abuse (National Survey of Child and Adolescent Well-Being - NSCAW). Results showed that nearly half (44\%) of mothers reported for child abuse were IPV victims. Comparing IPV mothers to mothers without this history, IPV mothers had more depression symptoms (46\% vs. 19\%), more frequent personal history of child abuse (26\% vs. $14 \%$ ), and lack of social support (35\% vs. $23 \%$ ). Children of IPV mothers were twice more likely to be reported for child abuse and in a shorter period of time, when compared to children of mothers without a history of IPV. 
Data supporting an association between a history of IPV and cases of child maltreatment were also observed in other relevant studies [3, 11-13], highlighting the need for integrative assessments by agencies that assist women. Thus, it is necessary not only to provide care to victimized women, but pay attention to their children's conditions, investigating the possibility of abuse by father, mother or both. IPV mothers need assistance to raise their children in a positive way, thus interventions with IPV and child abuse orientation should be promoted, especially because studies show that social support from a trusted adult (e.g. health professional), plus a positive mother-child training improves developmental outcomes in 4 to 9 years old children [5].

The ACE Study (Adverse Childhood Experiences Study) [14] is the largest research found in the literature on long-term health effects of a history of child abuse. The study sought to examine the relationship between multiple categories of childhood trauma and its consequences for health and behavior in adulthood. Data were collected over 17,000 participants through a questionnaire sent by mail. The categories of adverse childhood experiences studied were: recurrent physical abuse; recurrent emotional abuse; sexual abuse with penetration; alcohol and/or drug abuser in the household; incarcerated household member; household member chronically depressed, mentally ill, institutionalized, or suicidal; mother was treated violently; single parenthood or no parents; and emotional or physical neglect. These categories were then compared to the risk behavior in adulthood, health conditions and diseases.

Results showed that participants who reported having experienced four or more categories of adverse childhood experiences, compared with those who did not have any kind of adversity, had 4 to 12 times greater health risks related to alcohol abuse and/or drugs, depression and suicide attempts, 2 to 4 times higher risk associated with smoking and self-rated poor health, multiple sexual partners and sexually transmitted diseases; 1.4 to 1.6 times greater risk for physical inactivity and obesity. A relationship between adverse childhood experiences and heart disease, cancer, chronic lung disease, fractures and liver disease was also observed. The categories were highly correlated, and people who reported multiple categories were likely to have multiple risk factors for health in adulthood.

Another impact study conducted in a U.S. health agency [15] evaluated the experiences of violence in the childhood and its relation to the risk for IPV in 8629 participants. Researchers found that the practice of physical and sexual abuse in children twice increased the probability of women, as adults, to become victims of IPV and men perpetrators. About $25 \%$ of men and women were identified as victims of physical and/or sexual child abuse, and approximately $5 \%$ of men and women declared being at risk for perpetrating or being victims of IPV.

To be considered "exposed to violence" the children do not need to be present at the scene, they just need to have an IPV mother, as they do not need to watch the violent episode to be affected [16]. In addition, children exposed to IPV may present problems of social interaction, learning difficulties, health problems, behavioral difficulties, and risk of developing psychopathology [17-20].

The fact that most of the children of women victims of IPV witness the violence suffered by their mother is concerning because it influences the future of these children: how will the child propagate the aversive contingencies which they were submitted? Such children would eventually learn that power is frequently associated with aggressive behaviors and, therefore, that violence is good, acceptable and necessary to discipline or to express anger. In contrast, they may also learn a passive model, with a poor coping repertoire and frequent victimization. Thus, intervention with parents in violent contexts is important to guide them to educate their children properly, and to prevent family violence and its harmful consequences.

\subsection{Parenting Intervention}

Besides informing parents on appropriate educational methods, it is important to provide skills that effectively help them to set limits and rules to discipline, consistently, so that parents may be able to prevent and manage inappropriate child behavior, developing a closer relationship with their children. The last decades have been fertile in terms of research on parenting intervention, both to improve the relationship with their children, and to propose alternative efficient methods of educational practices. According to a literature review [21], the international programs recognized for having effective results to curb behavior problems in children are: the Oregon Social Learning Center [22], Incredible Years [23] and Triple P- "Positive Parenting Program" [24]. More recently, the ACT Against Violence: Parents Raising Safe Kids Program has also shown positive effects in primary prevention [25].

The themes worked in the Oregon Social Learning Center involve teaching parents about behavior problems, reinforcement and discipline techniques, adequate monitoring, and supervision strategies, as well as problem solving.

The Incredible Years Program aims at teaching skills for parents, teachers and children with a focus on the theme of prevention of behavior problems involving the whole community using video recordings, modeling behaviors and other well-researched techniques.

The Triple-P "Positive Parenting Program" is the project with higher number of systematic evaluations and it is designed to prevent the development of emotional behavioral problems in children by enhancing knowledge, skills and the confidence of parents, comprising five levels of intervention that maximize and help parents throughout the development of children (to age 16).

Finally, the ACT Against Violence: Parents Raising Safe Kids Program was developed by the American Psychological Association as a universal program to parents and caregivers to create early environments that protect them from violence. The program is organized into eight, 2-hour sessions to help parents understand children development, 
the importance of early positive stimulation (cognitive and affective), and also teaches positive parenting skills such as problem solving and the importance of reducing the influence of media violence on children.

In Brazil, some studies have conducted evaluations of programs designed to parents with a focus on prevention of aggressive behavior in children, with positive results. Marinho [26] described a 12 sessions training for 38 parents whose children had behavior problems with the following themes: differential attention, training in problem solving and discussion on various topics selected by parents (such as drugs, sex or religion) with an $\mathrm{AB}$ design with follow-up after 3 months. Results showed better performance in social education skills in parents, which helped to reduce delinquent and aggressive behavior in their children.

Baraldi and Silvares [27] conducted a study with 16 children and their mothers, who had complained about their children's aggressive behavior. The 32 participants were divided in two groups, experimental and control group, considering dyadic relations. Intervention addressed advices on anger management, differential reinforcement (ignoring the inappropriate behavior and praise the appropriate); extinction (in the case of behaviors like tantrums) to give instructions clearly and efficiently, and so on. The results showed improvement in performance of appropriate behavior, both for mothers and children, on the experimental group, which contributed to a positive result in the mother-child relationship.

Rios and Williams [28] conducted a study with five mothers and their children that focused on maximizing educational practices to prevent children behavior problems, using an $\mathrm{AB}$ design and a multiple baseline design. The themes involved information on child development, parental communication skills, appropriate discipline techniques, child abuse, parental positive monitoring, and moral behavior. Results indicated that mothers showed improvement in levels of parental satisfaction and efficacy, decreased use of inappropriate discipline techniques, increasing the number of positive interactions with their children.

All the previously mentioned studies on parent interventions selected had a cognitive-behavioral approach guiding the intervention, which is the model with the largest empirical support to date for interventions with parents [29, 30]. To provide significant positive results, important points of this approach should focus on: a) a reduction of re-occurrence of child abuse by helping parents learn how to use non aggressive discipline techniques, and anger management strategies, helping them change their dysfunctional beliefs about who is responsible for the abuse; b) a decrease in children's emotional problems while helping them process their abusive experiences and develop adaptive skills of cooperation; and c) an increase in positive parent-child interactions which are necessary for children's healthy development. Nevertheless, although the literature shows the high potential of co-occurrence of child behavior problems and violence within the family, none of the previously mentioned programs were specifically targeted to mothers with a history of IPV [31].

Letourneau et al. [5] highlighted the lack of programs, training and resources to assist IPV mothers to strengthen relationship with their infants and young children. In a retrospective qualitative study with 64 mothers exposed to IPV [32], researchers aimed at identifying participants' support needs, resources, barriers to support, and preferences for specific support interventions to promote optimal mother-infant relationships. Participants reported that integrated services including information and practical support from professionals associated with emotional and affirmation support from peers promoted positive, nurturing mother-infant relationships and healthy child development.

\section{The Projeto Parceria (Partnership Project)}

An example of a cognitive-behavioral intervention in Brazil that takes into account mothers' history of IPV is Projeto Parceria (Partnership Project) [33], with the goal of preventing behavior problems in children. It encompasses two units: a psychotherapeutic and an educational one. The psychotherapeutic unit is essential in dealing with the emotional aspects associated with a history of IPV, and other traumatic experiences to generate self-awareness and thereby maximizing the educational aspects of child behavior management. Another factor to be considered is that the intervention has a philosophy of considering mothers as partners of professionals, and not their subordinates.

Despite the current emphasis on systemic recommendations about the involvement of all family members, Projeto Parceria works exclusively with women, and does not involve the perpetrator for several reasons: a) the need for a prior intervention specific to the offender in order to reduce his aggressive behavior [34]; b) the fact that a considerable number of IPV women live apart from the partners due to the violence [35]; and c) the fact that there is lack of data so far on the parental role of IPV men as perpetrators [36]. A brief summary of the key features of Projeto Parceria is found in Table 1.

Projeto Parceria involves 16 weekly sessions, 8 sessions per unit*: a) A life free of violence (Unit 1), with topics such as The cycle of Violence, Human Rights, Violence against Women, Fighting Depression, which teaches mothers about the impact that violence may have had on their life, as well as violence prevention, self-protection and self-knowledge, and, b) Positive Parenting (Unit 2), with topics such as The Importance of Valuing Yours Children's Efforts, Setting Limits and Rules, Teaching Social Skills and Moral Behavior, and teaches positive parenting skills, employing techniques such as discussions based on written materials, relaxation training, social problem solving, homework, etc.

\footnotetext{
* The two manuals are available, in Portuguese, online and may be downloaded at LAPREV's website: www.ufscar.br/laprev
} 
Table 1. Key features of Projeto Parceria

\begin{tabular}{|c|l|}
\hline $\begin{array}{c}\text { Specific } \\
\text { Population }\end{array}$ & Mothers with a history of Intimate Partner Violence \\
\hline Focus & Preventing behavior problems in children \\
\hline $\begin{array}{c}\text { Conceptual } \\
\text { Principles }\end{array}$ & $\begin{array}{l}\text { Social learning theory and Cognitive-behavior } \\
\text { therapy }\end{array}$ \\
\hline $\begin{array}{c}\text { General } \\
\text { Intervention } \\
\text { Goals }\end{array}$ & $\begin{array}{l}\text { Dealing with the emotional aspects associated with a } \\
\text { history of IPV, and teaching positive parenting skills }\end{array}$ \\
\hline $\begin{array}{c}\text { Manuals } \\
\text { Content }\end{array}$ & $\begin{array}{l}\text { Unit } 1-\text { A life free of violence } \\
\text { Unit } 2 \text { - Positive Parenting }\end{array}$ \\
\hline Structure & $\begin{array}{l}\text { 16 weekly sessions (60 minutes each) } \\
\text { Pre-test, post-test and follow up procedure }\end{array}$ \\
\hline $\begin{array}{c}\text { Data } \\
\text { Collection }\end{array}$ & $\begin{array}{l}\text { Instruments and Inventories: with mothers and with } \\
\text { the target child } \\
\text { Observation: Mother-child interaction on home } \\
\text { replica laboratory }\end{array}$ \\
\hline
\end{tabular}

At the implementation phase of the project (pilot study) [37], 10 IPV mothers and their 10 target children participated of the intervention. They were sheltered and/or referred by the Judicial System, CPS, the Women's Police Station or self-referral. The mothers had children 4-12 years, and lived in a mid-size city of Sao Paulo State. Multiple evaluative measures were collected with the mothers: a Preliminary Interview with Battered Women [38]; The Parental Style Inventory (Inventário de Estilos Parentais - IEP) [39]; The Child Abuse Potential Inventory (CAP) [40], The Strengths and Difficulties Questionnaire (SDQ) [41], and the Beck Depression Inventory (BDI) [42]. Instruments with the children included: a Preliminary Interview with Children Exposed to Intimate Partner Violence [43]; IEP - Child version; and the SDQ - Child version. Two measures of self-recording by mothers were incorporated: Sense of Well-being, and Sense of Parental Competence, both consisting of a Daily Records on a scale of 0 to 10 .

Additionally, observational data of the mother-target child interaction was obtained. The interactions occurred in a 60 minute-session conducted at the University, at a house replica lab, containing cameras and one-way mirror in each room. The observational session was filmed using a protocol adapted from Triple P [24].

Table 2. A Summary of Projeto Parceria's studies

\begin{tabular}{|c|c|c|c|c|}
\hline & $\begin{array}{l}\text { Williams, Santini \& } \\
\text { D'Affonseca (2012) }\end{array}$ & $\begin{array}{l}\text { Pereira, D'Affonseca \& } \\
\text { Williams (2013) }\end{array}$ & Santini \& Williams (submitted) \\
\hline \multicolumn{2}{|r|}{ Participants } & $\begin{array}{l}10 \text { IPV mothers } \\
10 \text { target children (4-12 years old) }\end{array}$ & 17 IPV mothers & 9 IPV mothers \\
\hline \multirow{4}{*}{ 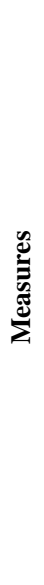 } & \multirow[t]{2}{*}{ Mother } & $\begin{array}{c}\text { Preliminary Interview with } \\
\text { Battered Women } \\
\text { IEP } \\
\text { CAP } \\
\text { SDQ } \\
\text { BDI }\end{array}$ & $\begin{array}{c}\text { Preliminary Interview with } \\
\text { Battered Women } \\
\text { IEP } \\
\text { CAP } \\
\text { SDQ }\end{array}$ & $\begin{array}{l}\text { Preliminary Interview } \\
\text { with Battered } \\
\text { Women } \\
\text { IEP } \\
\text { CAP } \\
\text { BDI }\end{array}$ \\
\hline & & \multicolumn{3}{|c|}{ Daily Records of Wellbeing and Sense of Parental Competence } \\
\hline & Child & $\begin{array}{l}\text { Preliminary interview with } \\
\text { children exposed to IPV } \\
\text { IEP (child version) } \\
\text { SDQ (child version) }\end{array}$ & & \\
\hline & Mother-child & $\begin{array}{l}\text { Recorded Observation of } \\
\text { mother-child interaction }\end{array}$ & & \\
\hline & Place & University (Day Hospital Unit) & Participant's home & $\begin{array}{c}\text { University } \\
\text { (Day Hospital Unit) }\end{array}$ \\
\hline & Results & $\begin{array}{l}\text { Improvement in parenting skills, } \\
\text { as well as reduced levels of } \\
\text { mothers' depression and the } \\
\text { potential risk for abuse }\end{array}$ & $\begin{array}{c}\text { Statistical significant } \\
\text { improvement in all measures }\end{array}$ & $\begin{array}{l}\text { The simultaneous approach group } \\
\text { showed significantly better results }\end{array}$ \\
\hline
\end{tabular}


The intervention lasted 16 weekly sessions (60 minutes each), followed by a follow-up after three months, and employed an AB design. All participants were assessed at the beginning and at the end of the intervention, comparing various performances of mothers and children. Evaluation of pre-intervention data indicated that all mothers participating in the project had deficits, both in their educational practices, as well as in behavioral and relationship problems. Observational data obtained showed a concerning difficulty from mothers to praise appropriate behaviors of children, although they were engaged in verbal interactions and appropriate instructions. In contrast, two mothers showed a high frequency of attention to all inappropriate behaviors of their target child, such as complaining, yelling and cursing. According to the Parental Styles Inventory, all mothers had an at-risk parenting style score. CAP Inventory scores showed high potential for abuse, indicating that these children had considerable probability of experiencing some type of abuse or neglect. SDQ scores of all mothers pertaining to their children fell in the "abnormal" category, indicating children's difficulties as problems of hyperactivity/attention deficit, anxiety and/or depression, in addition to behavior and relationship problems with peers. In terms of depression (BDI), 6 mothers showed moderate levels of depression, 2 mothers had mild depression score, one mother had a minimum rate of depression and one had a severe depression score.

Post-intervention and follow up data indicated an improvement in parenting skills, as well as reduced levels of depression and the potential risk for abuse. In the observations sessions, the results showed the efficiency of the home-lab as a tool for capturing mother-child interactions, allowing to identify and assess parenting skills which were present or not in mothers' repertoires, as well as appropriate or inappropriate behaviors of children [44].

Further studies based on Projeto Parceria with distinct populations obtained promising results. Pereira, D'Affonseca and Williams [45] implemented the project with 17 mothers of adolescents who were reported to the Judicial System of Brazil because they had been victims of multiple forms of abuse by various family members. As 15 of such mothers were also victims of IPV, Projeto Parceria was used. The families lived in extreme poverty and mothers had very low educational level (on average 2.8 years of study, 6 were illiterate). The intervention occurred weekly in the participant's home. The Preliminary Interview with Battered Women was applied in the first session, followed by IEP, CAP, SDQ at pre and post intervention and at a 3 month follow-up. In addition, participants also filled the Daily Records of Well-being and Sense of Parental Competence throughout the intervention. All mothers had 100\% attendance and mothers showed improvement in the scores evaluated at post-intervention and follow up with statistically significant data.

Santini and Williams [46] aimed at comparing the effectiveness of three different Project Parceria procedures:
Unit 1 preceded by Unit 2; b) Unit 2 preceded by Unit 1; and c) Units 1 and 2 presented simultaneously (one weekly session based on Unit 1, the following on Unit 2, and so forth). Nine women with a history of IPV whose children were aged 4-12 years participated of the study. Participants completed the same instruments used in Pereira's study: the Preliminary Interview with Battered Women, in the first session, and the following instruments: BDI, IEP and CAP in the pre-test post-test and follow up, and the Daily Rating Forms across the study of their Sense of Well-Being and their Sense of Parental Competence. A program evaluation by participants was conducted at the last meeting. After participants' screening, the interview was applied to compose the three groups evenly (according to income, years of schooling and cohabitation with the perpetrator were controlled). The intervention sessions were conducted individually. In total, the study involved 20 meetings at a Day Hospital Unit at the University. A non-randomized clinical trial with intra-group comparisons over time was employed [47]. The inventory data were analyzed using the JT Method, proposed by Jacobson and Truax [48], which evaluates the clinical significance of positive change and reliable scores. Additionally, data from the Daily Records were analyzed in terms of frequency, and content analysis was done in regards to the Program Evaluation. Positive results were found in the majority of scores, when comparing the pre-test with the post-test, and follow up with all groups. The simultaneous approach group (psychoterapeutic and educational) showed significantly better results when compared to others. Participants' evaluations of both units were also positive. Limitations of this study involve not controlling the variable severity of violence experienced by participants, as well as the inclusion of measures from other informants in data collection, such as from children and teachers. Table 2 summarizes Project Parceria's studies.

General results indicate that the strategy adopted by Project Parceria seems to be effective as it integrates two important topics to be worked with women victims of violence: the effects of the violence suffered, and behavior management of their children [37]. Moreover, Project Parceria Manuals have been well evaluated by participants, both in relation to its visual presentation and content. Mothers assessed the material as being useful, suggesting that it may be relevant to be implemented with this population in larger scale. An ongoing study is evaluating a positive education program to 40 physically aggressive mothers using Project Parceria's Unit 2 as the main material for intervention [49], with an experimental control group. Future studies may test Project Parceria more widely in randomized control evaluations.

\section{ACKNOWLEDGEMENTS}

Support for the research was provided by the Sao Paulo Research Foundation (FAPESP), Brazil, Grant \#2008/07997-2 and by the National Council for Scientific 
and Technological Development (CNPq), Brazil.

\section{REFERENCES}

[1] World Health Organization (2014). Child Maltreatment. Fact sheet 150. Retrieved from http://www.who.int/mediacentre/f actsheets/fs150/en/

[2] Belsky, J., Conger, R. \& Capaldi, D. M. (2009). The intergenerational transmission of parenting: Introduction to the special section. Developmental Psychology, 45, 1201-1204.

[3] Serbin, L. \& Karp, J. (2003). Intergenerational studies of parenting and the transfer of risk from parent to child. American Psychological Society, 12, (4), 138-142.

[4] Appel, A. E. \& Holden, G. W. (1998). The co-occurrence of spousal and physical child maltreatment: A review and appraisal. Journal of Family Psychology, 12, 578-599.

[5] Letourneau, N., Young, C., Secco, L., Stewart, M., Hughes, J. \& Critchley, K. (2011) Supporting mothering: Service providers' perspectives of mothers and young children affected by intimate partner violence. Research in Nursing and Health, 34, 192-203.

[6] U.S. Department of Health and Human Services (2008). Child Maltreatment 2006. Washington, DC: Author.

[7] Ribeiro, M. E., Eckert, E. R., de Souza, A. I. J. \& da Silva, A. M. F. (2007). Castigo físico adotado por pais acompanhantes no disciplinamento de crianças e adolescents [Parent's use of physical punishment to discipline their children and teenagers]. Acta Paulista de Enfermagem, 20 (3), 277-283.

[8] Santos, G. E. \& Williams, L. C. A. (2008). Prevenção terciária de problemas de comportamento infantil: Intervenção com pais que maltratam [Tertiary prevention of child behavior problems: Intervention with abusive parents]. In: E. G. Mendes, M.A. Almeida \& M.C.P.I. Hayashi (Eds). Temas em Educação Especial: Conhecimentos para fundamentar a prática (pp. 213-226). Araraquara: Junqueira \& Marin Editores/CAPES PROESP.

[9] Gallo, A. E. (2013). Brazilian young offenders: Profile and risk factors for criminal behavior. International Journal of Criminology and Sociology, 2, 163-168.

[10] Casanueva, C., Martin, S. L. \& Runyan, D. (2009). Repeated reports for child maltreatment among intimate partner violence victims: Findings from the National Survey for Child and Adolescent Well-Being. Child Abuse and Neglect, $33,84-93$.

[11] O’Leary, K. D. (1988). Physical aggression between spouses: A social learning theory perspective. In: V. B. Van Hasselt, R. L. Morrison, A. S. Bellack \& M. Hersen (Eds.) Handbook of family violence (pp. 31-55). New York: Plenum Press.

[12] Reitzel-Jaffe, D. \& Wolfe, D. A. (2001). Predictors of relationship abuse among young men. Journal of Interpersonal Violence, 16, 99-115.

[13] Stith, S, M. \& Farley, S. C. (1993). A predictive model of male spousal violence. Journal of Family Violence, 8, 183-201.
[14] Felitti, V. J., Anda, R. F., Nordenberg, D., Williamson, D. F., Spitz, A. M., Edwards, V., Koss, M. P. \& Marks, J. S. (1998). Relationship of childhood abuse and household dysfunction to many of the leading causes of death in adults: The Adverse Childhood Experiences (ACE) study. American Journal of Preventive Medicine, 14(4), 245-258.

[15] Whitfield, C. L., Anda, R. F., Dube, S. R. \& Felitti, V. J. (2003). Violent childhood experiences and the risk of intimate partner violence in adults: Assessment in a large health maintenance organization. Journal of Interpersonal Violence, $18,166-185$.

[16] Holden, G. A. (2003) Children exposed to domestic violence and child abuse: Terminology and taxonomy. Clinical Child and Family Psychology Review, 6(3), 151-160.

[17] Holt, S., Buckley, T. \& Whelan, S. (2008). The impact of exposure to domestic violence on children and young people: A review of the literature. Child Abuse \& Neglect, 32 (8), 797-810.

[18] Lansford, J. E., Dodge, K. A., Pettit, G. S., Bates, J. E., Crozier, J. \& Kaplow, J. (2002). A 12-year prospective study of the long-term effects of early child physical maltreatment on psychological, behavioral and academic problems in adolescence. Archives of Pediatric and Adolescent Medicine, 156, 824-830.

[19] Shields, R. G. \& Ciccheti, D. (1998). Reactive aggression among maltreated children: The contributions of attention and emotion dysregulation. Journal of Clinical Child Psychology, 27, 381-395.

[20] Toth, S. L., Ciccheti, D., \& Kim, J. (2002). Relationships among children's perceptions of maternal behavior, attributional styles and behavioral symptomatology in maltreated children. Journal of Abnormal Child Psychology, 30, 487-501.

[21] Rios, K. S. A. \& Williams, L. C. A. (2008). Intervenção com famílias como estratégia de prevenção de problemas de comportamento em crianças: uma revisão [Family intervention as a strategy to prevent behavior problems in children: A review]. Psicologia em Estudo, 13 (4), 799-806.

[22] Patterson, G. R., Reid, J. B. \& Eddy, J. M. (2002). A brief history of the Oregon Model. In J. B. Reid, G. R. Patterson \& J. Snyder (Eds.), Antisocial behavior in children and adolescents: A developmental analysis and model for intervention (pp. 3-21). Washington: American Psychological Association.

[23] Webster-Stratton, C., Reid, M. J., \& Hammond, M. (2004). Treating children with early-onset conduct problems: Intervention outcomes for parent, child, and teacher training. Journal of Clinical Child and Adolescent Psychology, 33(1), 105-124.

[24] Sanders, M. R. (2008). Triple P-Positive Parenting Program as a public health approach to strengthening parenting. Journal of Family Psychology, 22, 506-517.

[25] Knox, M., Burkhart, K., \& Cromly, A. (2013). Supporting Positive Parenting in Community Health Centers: The ACT Raising Safe Kids Program. Journal of Community Psychology, 41, 395 - 407.

[26] Marinho, M. L. \& Silvares, E. F. M. (2000). Evaluación de la eficacia de un programa de entrenamiento de padres en grupo [Evaluating the effectiveness of a group parenting training 
program]. Psicología Conductual, 8(2), 299-318.

[27] Baraldi, D. M., \& Silvares, E. F. M. (2003). Treino de habilidades sociais em grupo com crianças agressivas, associado à orientação dos pais: analise empírica de uma proposta de atendimento [Social skills training group with aggressive children, associated with parental guidance: An empirical analysis of a proposed service]. In A. Del Prette \& Z. A. P. Del Prette (Eds.). Habilidades sociais, desenvolvimento e aprendizagem (pp.235-258). Campinas: Alínea

[28] Rios, K. S. A. \& Williams, L. C. A. (2010). Um programa de intervenção sistemática com famílias de baixa renda para prevenção de comportamentos-problemas em crianças [A systematic intervention program with low-income families to prevent behavior problems in children]. In: L. C. A Williams, J. M. D. Maia \& K. S. A. Rios (Eds). Aspectos Psicológicos da Violência: Pesquisa e Intervenção CognitivoComportamental. (pp. 381-406). Santo André: ESETec.

[29] Kolko, D. J. (1996). Individual cognitive-behavioral treatment and family therapy for physically abused children and their offending parents: A comparison of clinical outcomes. Child Maltreatment, 1, 322-342.

[30] Corcoran, J. (2000). Family interventions with child physical abuse and neglect: A critical review. Children and Youth Services Review, 22, 563-591.

[31] Runyon, M. K., Deblinger, E., Ryan, E. E. \& Thakkar-Kolar, R. (2004). An overview of child physical abuse: Developing and integrated parent-child cognitive-behavioral treatment approach. Trauma, Violence \& Abuse, 5, 65-85.

[32] Letourneau, N., Morris, C.Y., Secco, L., Stewart, M., Hughes, J., Critchley, K. \& Secco, L. (2013). Social support needs identified by mothers affected by intimate partner violence. Journal of Interpersonal Violence, 28(14), 2873-2893.

[33] Williams, L. C. A., Padovani, R. C. \& Brino, R. F. (2009). Empowering families to face domestic violence. Best practices in gender, ethnicity and health. São Carlos: EDUFSCar/OPAS.

[34] Cortez, M. B., Padovani, R. C. \& Williams, L. C. A. (2005). Terapia de grupo cognitivo-comportamental com agressores conjugais [Cognitive behavioral group therapy with batterers]. Estudos de Psicologia, 22, (1), 13-21.

[35] Zeoli, A. M., Rivera, E.A., Sullivan, C. M. \& Kubiak, S. (2013). Pos-separation abuse of women and their children: Boundary setting and family court utilization among victimized mothers. Journal of Family Violence, 28(6), 547-560.

[36] Stover, C. S. \& Morgos, D. (2013). Fatherhood and intimate partner violence: Bringing the parenting role into intervention strategies. Professional Psychology: Research and Practice, 44(4), 247-256.

[37] Williams, L. C. A., Santini, P. M. \& D'Affonseca, S. M. (2012). A mothering skills program for women with a history of domestic violence: An analysis of mother-child interaction. In: H. Dubowitz (Eds.). World perspectives on child abuse. (pp. 134-136). 10 $0^{\text {th }}$ ed. Turkey: International Society for the Prevention of Child Abuse and Neglect (ISPCAN).

[38] Williams, L. C. A (2010a). Entrevista inicial a mulheres vítimas de violência doméstica. [Preliminary interview with battered women]. In: L. C. A Williams, J. M. D. Maia \& K. S. A. Rios (Eds). Aspectos Psicológicos da Violência: Pesquisa e Intervenção Cognitivo-Comportamental. (pp.549-559). Santo André: ESETec.

[39] Gomide, P. I. C. (2006). Inventário de Estilos Parentais (IEP) [Parenting Styles Inventory]. Petrópolis, RJ: Editora Vozes.

[40] Milner, J. S. (1994). Assessing physical child abuse risk: The Child Abuse Potential Inventory. Clinical Psychology Review, 6 (14), 547-583.

[41] Fleitilich-Bilyk, B. \& Goodman, R. (2001). Social factors associated with child mental health problems in Brazil: Cross sectional survey. British Medical Journal, 323, 599-600.

[42] Beck, A.T., Rush, A.J., Shaw, B. F. \& Emery, G. (1979). Cognitive Therapy of Depression: A treatment manual. New York: Guilford Press.

[43] Williams, L. C. A (2010b). Entrevista inicial com crianças expostas a violência conjugal [Preliminary interview with children exposed to intimate partner violence]. In: L. C. A Williams, J. M. D. Maia \& K. S. A. Rios (Eds). Aspectos Psicológicos da Violência: Pesquisa e Intervenção Cognitivo-Comportamental. (pp. 560-564). Santo André: ESETec.

[44] Rios, K., D'Affonseca, S. M., Santini, P. M., Lessa, T., Patrian, A. C. A., Miranda, T. D., Williams, L. C. A. (2010). Uma casa-laboratório como recurso tecnológico para o ensino de habilidades parentais e prevenção de problemas de comportamento infantil [A house-laboratory as a technological resource to teach parenting skills and prevention of behavior problems in children]. In: M. M. C. Hubner, M. R. Garcia, P. R. Abreu, E. N. P. de Cillo \& P. B. Faleiros (Eds.). Sobre Comportamento e Cognição - Terapia Comportamental e Cognitivas. Vol 25. Santo André - SP: ESETec.

[45] Pereira, P.C., D’Affonseca, S. M. \& Williams, L. C. A. (2013). A feasibility pilot intervention program to teach parenting skills to mothers of poly-victimized children. Journal of Family Violence, 28, 5-15.

[46] Santini, P. M. \& Williams, L. C. A. (submitted). Efeitos de procedimentos para maximizar bem-estar e competência parental em mulheres vitimizadas [Effects of procedures to maximize well-being and parental competence in victimized women].

[47] Hulley, S. B., Cummings, S. R., Browner, W. S., Grady, D., Hearst, N. \& Newman, T. B. (2006). Designing clinical research: an epidemiologic approach $\left(3^{\text {rd }} \mathrm{ed}\right)$. Baltimore: Lippincott Williams \& Wilkins.

[48] Jacobson, N. S \& Truax, P. (1991). Clinical significance: A statistical approach to defining meaningful change in psychotherapy research. Journal of Consulting and Clinical Psychology, 59(1), 12-19.

[49] Santini, P. M. (2013). Intervenção a mães com histórico de agressões físicas a seus filhos: Efeitos de recursos tecnológicos [Intervention to mothers with a history of physical aggression towards their children: Effects of technological resources]. Ongoing PhD Dissertation. Federal University of São Carlos, Brazil. 